\title{
The Role of Assets in the Enhancement of Households' Income: A Study of Poverty Alleviation among Rural Communities of Kelantan and Terengganu
}

\author{
Senadjki Abdelhak ${ }^{1}$, Jamalludin Sulaiman ${ }^{1} \&$ Saidatulakmal Mohd $^{1}$ \\ ${ }^{1}$ School of Social Sciences, Universiti Sains Malaysia, Penang, Malaysia \\ Correspondence: Senadjki Abdelhak, Economic Department, School of Social Sciences, Universiti Sains \\ Malaysia USM, 11800, Penang, Malaysia. Tel: 60-12-429-0450. E-mail: absenadjki@gmail.com
}

Received: May 4, 2012 Accepted: June 25, 2012 Online Published: August 17, 2012

doi:10.5539/ass.v8n11p145

URL: http://dx.doi.org/10.5539/ass.v8n11p145

\begin{abstract}
This paper aims to examine the role of assets and entitlements on the enhancement of farmers' income. Using a structured socio-economic questionnaire, 302 randomly selected farmers in both Kelantan and Terengganu states were tested. To answer the study's objectives, one way ANOVA test was carried out and tested. The results indicated that access to land, fertilizers, tractors, and health facilities, quality of housing, market, and livestock have significant positive impact on farmers' wellbeing. Access to irrigation and having savings (at banks and/or homes) were found to have significant negative impact on farmers' monthly income. Education and association memberships are not essential factors that might contribute to the enhancement of farmers' livelihood. Investing in productive assets was found to be more effective rather than safekeeping the money in a bank or at home. However, households and farmers deal with their own assets and entitlement differently. As a result, assets are found to decrease the income of farmers partially due to the farmers' decision-making strategies which seems to be poor and inadequate. Therefore, incorporating psychological perspective such as farmers' behaviours and perceptions are utmost important in order to better understand the complex mechanisms underlying the farmers who are falling in poverty trap.
\end{abstract}

Keywords: poverty eradication, assets, small holder farmers

\section{Introduction}

When Sen (1981) published his famous book Poverty and Famines, he altered the idea of famine is mainly occurred due to biophysical events such as flood and drought to lack of entitlements. Sen (1981) believes that famines occur without any decline of food availability. But lack of entitlement and the distribution of this entitlement among individuals and households is a significant factor that determines the vulnerability to famine. He then conceptualized his entitlement approach as a model that explains vulnerability to famine in terms of resources availability to individuals based on their own capacities and capabilities (Adger, 2006). Many scholars and researchers have criticized Sen's entitlement approach. Geest and Dietz (2004) argued that this approach neglects the historical structural processes that cause the unequal distribution of entitlements to resources, and fails to explain the recovery process after a disaster. Devereux (2001, p259) stated that Sen's approach fails in recognizing individuals as socially embedded members of households, communities and states; and fails to recognize that famines are political crises as much as they are economic shocks or natural disasters.

Even though Sen's entitlement approach generated lot of criticisms; many researchers follow his theory and investigate the impact of assets, entitlement and empowerment on households' vulnerability to poverty. Carter et al (2007) found that poor rural Ethiopian households who have few assets and experienced drought are unable to rebuild their herds. Osman-Elasha et al (2006) found that to reduce households' vulnerability to climate change in Sudan; government must invest in building poor households' capabilities to respond against climate change and natural disaster as well as other stresses. These interventions vary in nature such as access to natural, physical, financial, human and social assets. While Jehangir et al (2002) stated that credit, labour, fertilizers and reducing cost of production are positively affecting the farms' income. Babatunde (2008) pointed out that failure in many poverty reductions has been because policymakers and practitioners ignored the great diversity and 
heterogeneity in assets portfolios across households. All above studies assert that households use their resources rationally. But owing an assets and entitlements may not be sufficient in eradicating poverty if households behave inadequately (Scaramozzino, 2006) and if households live in prone areas and also if they live in areas where there are no well developed markets (Hanjra et al., 2009; Acosta-Michlik \& Espaldon, 2008; Kapoor \& Ojha, 2006). This study argues that use of resources will not enhance households' welfare unless these resources are used strategically. Households sometimes implement strategies that exacerbate their livelihoods. Implementing the wrong strategies in coping with and manage against uncertainties will lead to unfavorable consequences. This study aims to add research value to previous knowledge by investigating how assets and entitlements improve farmers' wellbeing. It also tries to find out if access to these assets and entitlements lead farmers to behave and perform insufficiently, therefore exacerbate their poverty.

\section{Data and Research Method}

To investigate the role of assets and entitlement on farmers' wellbeing, this study uses a quantitative research method. Data was collected with the use of a structured socio-economic questionnaire containing both open and close-ended items. The questionnaire administration is cross-sectional in nature. A pilot test was carried out to test the validity and reliability of the questionnaire instrument, and to ensure that the questionnaire can be understood and accepted by the respondents who are farmers. The pilot study was conducted on 50 farmers in Kelantan and Terengganu in November 2010. A multistage sampling technique was used for the representative households. The first stage was the selecting the two states: Terengganu and Kelantan. The main reason for selecting the two states is because these two states have the highest poverty incidence within peninsular Malaysia (EPU, 2010). They are also the two states most exposed to natural disaster such as flood (Noriyah Ahmad, 2007). The second stage was the selection of three rural districts (strata). These areas include: Pasir Putih in Kelantan and Besut and Setiu in Terengganu. In the third stage, the household farmers were then randomly selected and surveyed. In order to get an accurate data and minimize bias, the questionnaire using the local language (i.e. Bahassa Malaysia) was distributed directly to the respondents and was clearly explained to the respondents. Between January and February 2011, 400 questionnaires were distributed to the respondents but only 302 surveys were completed in the three communities with the following breakdown: 100 questionnaires in Pasir Putih, 102 in Besut and 100 in Setiu. The 302 completed questionnaires were analysed using Statistical Package for Social Sciences (SSPS) for windows version 17 program. In order to evaluate the effectiveness of various types of assets and entitlements on households' wellbeing, one way ANOVA test was carried.

\section{Measurement of Variables}

To measure the research variables a wide range of measuring scales and strategies were used. The items were adapted and adopted from previous studies. Some items were developed by the researcher. The dependent variable is households' monthly income. The independent variables are human capital; social capital; physical capital; natural capital and financial capital

\subsection{Households' Capacity}

Households' capacity was measured as the total set of assets that households own or have access to. An asset is identified as a stock of financial, human, natural, physical or social resources that can be acquired, developed, improved and transferred across generations. It generates flows or consumption, as well as additional stock (Moser, 2006, p5).

Human capital was measured as the household's level of education and health situation which determines his capacity to work. Social capital measured included the informal networks, membership of citizen's associations and relationships of trust that facilitate co-operation. Natural capital measured included the resources that households could acquire from nature such as land, soil, water, forests and fisheries. Physical capital was measured as the basic infrastructure that households had such as roads, water \& sanitation, schools, tools and equipment. Whereas financial capital measured included the savings, credit, and income from employment, trade and remittances that household owe or acquire (Haidar, 2009). Households were then asked to indicate their assets (human, social, physical, natural and financial) from a given list

\section{Results and Discussion}

\subsection{The Effects of Households' Capacities on Their Wellbeing}

\subsubsection{The Human Capital}

To evaluate the effectiveness of various types of assets and entitlements on households' wellbeing, a one way ANOVA test was carried. Using a tukey HSD test, the results in table 1 indicated that most of the selected variables of human capital model are significantly affecting households' wellbeing. Those who had not 
experienced sickness were found to have different mean monthly income from those who had experienced sickness. Results showed that households who had not experienced a sickness have much higher mean monthly income than those who had experienced sickness. Also those who had experienced sickness, but these sickness did not limit their activities were found to have mean monthly income much higher than those who had experienced sickness that limited their activities. Households who had been hospitalised were found to have lesser mean monthly income than those who did not acquire hospital treatments. Also the results depicted households who had access to health clinic had much higher mean monthly income compared to those who purchase medications from pharmacies or use traditional medications. These results substantiate findings by Wie (2001). Overall, the presence of unhealthy productive households reduces monthly income by RM210 compared to productive household who did not experience any sickness. The more number of times "productive and non-productive" households got sick or acquired hospital treatment, the less monthly income these households attained. The healthy situation of households contributed to increase their monthly income directly and indirectly. Directly by increasing households' working hours and increase their productivity and production in both on-farm and off-farm activities. Also they participate in activities and programs provided by government's agencies, NGOs and CBOs. Indirectly by reducing the "cost of sickness" that included the expenditure of medical treatments; and the opportunity cost that occurs as households are being jobless during the period of being sick.

Educational level seems not to have any effect on households' wellbeing. The results indicated that there is no difference in the mean monthly income among those who had no formal education and those who had formal education. No formal education, primary and secondary education did not significantly increases the value of agricultural equipment, productive assets and farm size. These results are similar to Wie's (2001) who found that more years in education do not always bring households a higher income. And contradict Fafchamps and Quisumbing (1998) who found that one additional year of schooling for all adult males raises household incomes by 4.5 percent. Also the results contradict Bokosi (2007) results which indicated that the probability of being poor in Malawi was reduced by $32.5 \%$ and $11 \%$ for those households whose head attended secondary and primary school respectively between years 1998-2002. And also contradicts Owuor et al (2007) results which stated that education of head influence the probability of households existing chronic poverty. This can be explained by the fact that most of the farm activities for those smallholder farmers are based on the farmers' experiences and skills. We then, affirm that in these communities, it is the skills attained in daily practices that raise the households' productivity, not their formal education. Oladoja and Olusanya (2009) recommended research institutes in collaboration with extension agencies to conduct trainings and workshops for farmers to build and increase their capacities, skills and knowledge in order to boost their productivity and productions thus escaping poverty trap. Therefore, it is level of skills and "health situation" for both productive and non-productive households that play the most important role in increasing their monthly income and not their formal education.

Table 1. Results of Post Hoc Tests for human capital variables

\begin{tabular}{|c|c|c|c|c|c|}
\hline Variables & Scale & & Mean Difference & Std. Error & Sig. \\
\hline \multirow{3}{*}{$\begin{array}{l}\text { Number of times } \\
\text { being sick }\end{array}$} & \multirow[t]{3}{*}{ None } & $1-3$ & $243.202^{*}$ & 49.406 & .000 \\
\hline & & $4-6$ & $182.487^{*}$ & 63.349 & .034 \\
\hline & & $7-10$ & $366.687^{*}$ & 82.895 & .000 \\
\hline \multirow{3}{*}{$\begin{array}{ll}\text { Do these } & \text { illness } \\
\text { limit } & \text { your } \\
\text { activities } & \end{array}$} & \multirow[t]{3}{*}{ No } & Yes, productive household member & $210.180^{*}$ & 63.188 & .005 \\
\hline & & $\begin{array}{l}\text { Yes, non productive household } \\
\text { member }\end{array}$ & $235.762^{*}$ & 67.058 & .003 \\
\hline & & $\begin{array}{l}\text { Yes, productive and non productive } \\
\text { members }\end{array}$ & $261.114^{*}$ & 52.604 & .000 \\
\hline \multirow{2}{*}{$\begin{array}{l}\text { How many times } \\
\text { have you required } \\
\text { hospital treatment }\end{array}$} & \multirow[t]{2}{*}{ None } & $1-3$ & $251.307^{*}$ & 47.142 & .000 \\
\hline & & $4-6$ & $207.487^{*}$ & 76.621 & .020 \\
\hline \multirow{3}{*}{$\begin{array}{l}\text { Where do you get } \\
\text { your medicines }\end{array}$} & \multirow{3}{*}{$\begin{array}{l}\text { Health } \\
\text { clinic }\end{array}$} & Pharmacy & $295.333^{*}$ & 98.850 & .036 \\
\hline & & Traditional medication & $249.767 *$ & 46.711 & .000 \\
\hline & & Faith healer & 267.000 & 184.931 & .700 \\
\hline \multirow[t]{4}{*}{ Educational level } & & STD 5/6 & 91.471 & 59.497 & .539 \\
\hline & \multirow{3}{*}{$\begin{array}{l}\text { No formal } \\
\text { education }\end{array}$} & PMR/LCE & 164.444 & 68.233 & .115 \\
\hline & & $\mathrm{SPM} / \mathrm{MCE}$ & 12.759 & 56.678 & .999 \\
\hline & & University & -435.556 & 271.060 & .494 \\
\hline
\end{tabular}

(*) denotes that the mean difference is significant at $1 \%$ level 


\subsubsection{The Social Capital}

Compared to human capital, the variables of social capital model were not significantly affecting households' wellbeing. The results from table 2 depicted that people who had been helped by relatives, friends, and citizens' association had no difference in their mean monthly income with those who have not been helped.

In contrast to most previous studies at the micro level (Narayan and Pritchett, 1999; Maluccio et al., 1999; Ruben and Strien., 2001; Schwarze and Zeller, 2005, Mathbor, 2007) which found that social capital has a significant effect on the income of households. The impact of social capital on the income of rural households in the present study is not significant and does not play any important role in alleviating households' vulnerability to poverty. Opposite to previous findings (Grootaert, 1999; Grootaert and Narayan, 1999; and Grootaert et al., 2002), and in accordance with Van Ha, et al (2004) and Walusimbi and Nkonya (2004) findings; the association memberships do not have an impact on the improvement of rural households' income in these three communities. Hence, this finding does not mean that social capital should not receive any priority in policy interventions directed toward the enhancement of rural communities' wellbeing. The inefficient and ineffective role of social capital in building up households' capacities can be explained by two facts. First of all, lack of access to or even the absence of these citizens' associations. Data showed that only five percent of the respondents have membership in these citizens' association. More than 55 percent of those who have memberships were not helped even a single time. Also, this type of memberships acquiesce little or no benefit for its members but costs them membership fees, their time, and energy (Van Ha et al., 2004). Second, majority of households' respondents in these communities were poor and even lived in hardcore poverty $(9.9 \%$ of the respondents found to live in hardcore poverty, $60.3 \%$ are poor). To live within poor group of people and with fewer assets, is very hard to be able to find a help from others then escape poverty. People are unable to help their relatives and friends if they also are poor. Data show that more than 63 percent of the respondents never get helped by their relatives and friends. Even those who are getting assistance from their friends and relative, this assistance is remaining marginal, and cannot move the poor family forward.

Table 2. Results of Post Hoc Tests for social capital variables

\begin{tabular}{lllccc}
\hline Variables & Scale & & Mean Difference & Std. Error & Sig. \\
\hline $\begin{array}{l}\text { How many friends } \\
\text { and relatives do you }\end{array}$ & & $6-10$ & 136.987 & 62.703 & .188 \\
have & & $11-15$ & -.491 & 72.046 & 1.000 \\
& & $16-20$ & -152.319 & 77.626 & .287 \\
& & -225.652 & 174.339 & .695 \\
$\begin{array}{l}\text { How many times did } \\
\text { they help you }\end{array}$ & & 2 times & -121.667 & 62.405 & .374 \\
& & 3 times & 56.717 & 57.688 & .923 \\
& & 4 times & 296.111 & 127.891 & .191 \\
$\begin{array}{l}\text { How many times you } \\
\text { got assistance from }\end{array}$ & None & More than 4 & 346.111 & 155.386 & .228 \\
citizens' associations & & Not applicable & 258.016 & 144.246 & .475 \\
\hline
\end{tabular}

$(*)$ denotes that the mean difference is significant at $1 \%$ level

\subsubsection{The Natural Capital}

The variables of natural capital model showed a significant impact on households' monthly income. Table 3 indicated that those who had access to land had much higher income than those who lack access to land. Land size, have a significant effect on equipment and livestock value. Data show that those who have more acres of land had more equipments and productive assets. It also significantly increased the productivity and production of households. Access to fertilizers, pesticides, herbicides also positively affected households' wellbeing. People who used more fertilizer (in term of quantity) in their production activities had much higher mean monthly income than those who used less fertilizer. These results are similar to Jehangir et al (2002) and Omolehin et al (2007). This indicates that the quality of land is the same in these communities. Using much fertilizers for higher productivity and production indicate that farmers in these area had low land quality. Those who received subsidies from government had much higher mean monthly income than those who had no access to fertilizers or had to purchase them. 
Also the results indicated that households who were able to produce and sell some of their productions have much higher mean monthly income than those who are not able to produce. But those who produce and consumed some, consume all or/and couldn't sell, have no significant difference in their mean monthly income.

Surprisingly access to irrigation seems to have no effect on households' wellbeing. The results indicated that those who depended on rainfall for their agricultural activities had much higher mean monthly income than those who had access to irrigation. Many studies confirmed that investment in irrigation is a fundamental element in enhancing farm productivity therefore eradicating poverty. Hussain and Hanjra (2003), Hussain, Hanjra (2004) and Ashfaq et al (2001) Khan and Nafees (2002) found strong linkages between irrigation, agricultural productivity and poverty reduction. While others found that there exist no significant relationship between irrigation and the farms' income (Jehangir, 2002).

The results of the present study contradict the hypothesis that signifies that irrigation lead to poverty eradication. The results showed that those who have access to irrigation have less mean monthly income than those who depend solely on rainfall. More than 63 percent of those who do not have access to irrigation had employed multiple jobs strategy to increase their income and less than 40 percent of those who have access to irrigation had employed this strategy. Also 45 percent of those who do not have access to irrigation had employed less risky production activities and only 20 percent of those who have access to irrigation had employed this strategy. Therefore, those who have access to irrigation feel more safe, then they just involved in limited activities that prevent them from any unexpected events; consequently, they became more vulnerable to income diversification. As a result, access to resources may not enhance households' welfare unless these resources are used adequately and effectively. Households' behaviour is an important element that determines the effective strategy that should be implemented.

Table 3. Results of Post Hoc Tests for natural capital variables

\begin{tabular}{|c|c|c|c|c|c|}
\hline Variables & Scale & & $\begin{array}{c}\text { Mean } \\
\text { Difference }\end{array}$ & Std. Error & Sig. \\
\hline \multirow{6}{*}{$\begin{array}{l}\text { What is the size of the land } \\
\text { you or one of your } \\
\text { households member own } \\
\text { or manage }\end{array}$} & \multirow[t]{6}{*}{ More than 5} & I do not have & $1023.001^{*}$ & 50.195 & .000 \\
\hline & & less than 1 & $1022.217^{*}$ & 43.081 & .000 \\
\hline & & 1 & $988.522^{*}$ & 50.895 & .000 \\
\hline & & 2 & $856.093^{*}$ & 52.927 & .000 \\
\hline & & 3 & $453.871^{*}$ & 78.557 & .000 \\
\hline & & 4 & $450.538^{* *}$ & 130.609 & .011 \\
\hline \multirow{6}{*}{$\begin{array}{l}\text { How much fertilizers you } \\
\text { use }\end{array}$} & \multirow{6}{*}{$\begin{array}{l}\text { More than } \\
50\end{array}$} & $0-10 \mathrm{~kg}$ & $409.722^{* *}$ & 124.407 & .019 \\
\hline & & $11-20 \mathrm{~kg}$ & $249.405 * *$ & 84.577 & .050 \\
\hline & & $21-30 \mathrm{~kg}$ & $250.000^{* *}$ & 79.831 & .031 \\
\hline & & $31-40 \mathrm{~kg}$ & $243.640 * * *$ & 88.377 & .088 \\
\hline & & $41-50$ & $230.911^{*}$ & 62.923 & .005 \\
\hline & & Not applicable & $294.643^{*}$ & 63.497 & .000 \\
\hline \multirow{3}{*}{$\begin{array}{l}\text { What is the main sources } \\
\text { of fertilizers, pesticides, } \\
\text { herbicides and seeds that } \\
\text { you use in your farming }\end{array}$} & \multirow{3}{*}{$\begin{array}{l}\text { Government } \\
\text { subsidies }\end{array}$} & No access & $291.296^{*}$ & 66.024 & .000 \\
\hline & & Purchase & $340.714^{* *}$ & 111.124 & .048 \\
\hline & & CBOs \& NGOs & 222.857 & 103.756 & .387 \\
\hline \multirow{3}{*}{$\begin{array}{l}\text { What is the source of } \\
\text { water on this land }\end{array}$} & & Rainfall & $-452.041 *$ & 160.632 & .027 \\
\hline & Irrigation & Irrigation \& rainfall & -260.732 & 59.056 & .007 \\
\hline & & Not applicable & -109.524 & 78.095 & .000 \\
\hline \multirow{3}{*}{$\begin{array}{l}\text { Did you sell any of your } \\
\text { production }\end{array}$} & \multirow{3}{*}{$\begin{array}{l}\text { Produce and } \\
\text { sold some }\end{array}$} & No produce & $281.633^{*}$ & 49.389 & .000 \\
\hline & & Produce but consume all & 117.782 & 57.714 & .175 \\
\hline & & Produce but cannot sell & -87.879 & 260.035 & .987 \\
\hline
\end{tabular}

$(*),(* *),(* *)$ denotes that the mean difference is significant at $1 \%, 5 \%$ and $10 \%$ level respectively

4.1.4 The Physical Capital

Similar to natural capital, access and owing physical assets found to be an essential variable towards the enhancement of households' livelihoods. Table 4 depicted that most of the selected variables of physical capital model are significantly improving households' welfare. The results indicated that those who had no problems 
with their accommodation have much higher mean monthly income than those who had some harms in their dwellings. Whereas, access to these dwelling showed no significant effect on households' monthly income, households who access their accommodation through either footpath, unpaved road or paved roads, have no significant difference in their mean monthly income. Owing productive and non-productive assets is vital to build up households capacities.

People who had more cows, goats, hens and ducks; and people who had stored foods and other valuable things that can be transformed to liquidity had much higher mean monthly income than those who had lesser hens and ducks or those who have lesser food and equipments storage. These findings similar to Bokosi (2007) results which stated that a unit increase in the value of percapita value of livestock owned reduce the probability of being poor in Malawi by 3 percent between years 1998-2002. Also Owuor et al (2007) found that livestock assets significantly contribute to the reduction of the probability of being chronically poor. Households who use mechanical tractor in their agricultural activities have much higher mean monthly income than those who use manual cultivations. These results are similar to Shah et al (2006) which indicated that adopting improved production technology increases more than 3 times over the provincial mean wheat yield in Pakistan, therefore increase farm' revenues. Owing productive assets rather than nonproductive assets, as primary source of income, significantly increases farms productivity and production. Results of the present study depicted that those who had more livestock (cows, sheep, hens and ducks), mechanical tractors, land and fertilizers produce more. The surpluses of their production (after consuming or storing their families' needs) were sold in local markets. Therefore, marketable surplus leads to higher income generation thereby reduce poverty among rural farmers (Omolehin et al., 2007).

Table 4. Results of Post Hoc Tests for physical capital variables

\begin{tabular}{|c|c|c|c|c|c|}
\hline Variables & Scale & & $\begin{array}{c}\text { Mean } \\
\text { Difference }\end{array}$ & Std. Error & Sig. \\
\hline \multirow{4}{*}{$\begin{array}{l}\text { Do you have any problems } \\
\text { with your accommodation }\end{array}$} & \multirow{4}{*}{$\begin{array}{l}\text { No } \\
\text { problems }\end{array}$} & Shortage of rooms & $348.866^{*}$ & 80.083 & .000 \\
\hline & & Leaky roof & $204.205^{*}$ & 54.098 & .004 \\
\hline & & Damp walls, floors, foundations & $284.183^{*}$ & 73.084 & .002 \\
\hline & & Rot in window frames or floors & $267.169^{*}$ & 76.226 & .009 \\
\hline \multirow{3}{*}{$\begin{array}{l}\text { Access to your accommodation } \\
\text { is through? }\end{array}$} & \multirow[t]{2}{*}{ Footpath } & Unpaved road & 57.576 & 169.116 & .938 \\
\hline & & Paved road & 204.563 & 157.329 & .396 \\
\hline & \multirow[t]{3}{*}{$21-30$} & None & $479.881^{*}$ & 77.470 & .000 \\
\hline \multirow{2}{*}{$\begin{array}{l}\text { How many hens and ducks do } \\
\text { you have? }\end{array}$} & & Less than 10 & $543.685^{*}$ & 74.837 & .000 \\
\hline & & $11-20$ & $338.884^{*}$ & 60.679 & .000 \\
\hline \multirow{6}{*}{$\begin{array}{l}\text { How many heads of cows and } \\
\text { oxen do you have? }\end{array}$} & \multirow{6}{*}{ None } & One & $-310.460 * * *$ & 220.399 & .097 \\
\hline & & Two & $-230.460 * * *$ & 79.743 & .062 \\
\hline & & Three & $-110.460 * * *$ & 145.473 & .088 \\
\hline & & Four & $-260.460 * *$ & 191.265 & .022 \\
\hline & & Five & $-189.540 *$ & 220.399 & .000 \\
\hline & & More than five & $-218.111^{*}$ & 86.346 & .000 \\
\hline \multirow{4}{*}{$\begin{array}{l}\text { How many heads of goats and } \\
\text { sheep do you have? }\end{array}$} & \multirow{4}{*}{ None } & Less than five & $-184.839 * *$ & 103.842 & .038 \\
\hline & & $6-10$ & $-249.774 * *$ & 84.034 & .026 \\
\hline & & $11-15$ & $-180.077 * *$ & 219.793 & .025 \\
\hline & & $16-20$ & $-63.410^{*}$ & 268.680 & .009 \\
\hline \multirow{3}{*}{$\begin{array}{l}\text { How much food or other } \\
\text { valuable things do you store in } \\
\text { your house? }\end{array}$} & \multirow{3}{*}{$\begin{array}{l}\text { More } \\
\text { than } \\
\text { RM500 }\end{array}$} & None & $595.280^{*}$ & 66.826 & .000 \\
\hline & & Less than RM100 & $511.024^{*}$ & 61.149 & .000 \\
\hline & & RM100-500 & $216.550^{*}$ & 62.942 & .004 \\
\hline \multirow{3}{*}{$\begin{array}{l}\text { What is the main source of } \\
\text { tailing }\end{array}$} & \multirow{3}{*}{ No tilling } & Manual cultivation & $-169.140 * *$ & 62.784 & .037 \\
\hline & & Mechanical tractor & $-377.622^{*}$ & 92.593 & .000 \\
\hline & & Mechanical \& manual cultivation & $-218.375^{* *}$ & 78.521 & .029 \\
\hline
\end{tabular}

$(*),(* *),(* * *)$ denotes that the mean difference is significant at $1 \%, 5 \%$ and $10 \%$ level respectively

It is therefore likely that households who own fewer productive assets are likely to be poor, as they have low 
productivity and production. However, it is likely that households who have fewer assets work much harder to compensate for their disadvantaged position. The results indicated that 63 percent of those who had fewer assets did multiple jobs. Owing fewer assets may decrese households' livelihoods. According to the study, 71 percent of those who have fewer assets reported that they reduced the quality and quantity of their diet and asked for loans from others. This may harm their health and put them in grave position as they cannot pay back their loans. As a result, their productivity declined and also limited their activities and in some cases sell the few assets they owned. They eventually ended living in chronic poverty.

\subsubsection{The Financial Capital}

It is not possible to conduct tukey HSD test for variables measured as a dummy,. Therefore, Pearson correlation was used to investigate the nature of relationship that existed between financial capital and households' monthly income. The results of tukey HSD test indicated that there existed a negative relationship between financial capital and monthly income. The results of this study contradict Jehangir et al (2002) and Owuor et al (2007) findings which indicated that there exists a significant positive relationship between the amount of credit and the farms' monthly income.

While human, natural and physical capitals have all positive effects on households' livelihood; financial capital is negatively affecting their monthly income. The more saving households had, the lesser monthly income households obtained $(r=-0.387, p=0.000)$. Therefore, access to financial capital also may lead to deterioration of households' wellbeing if they (households) were to inappropriately utilize these resources. Those maintaining saving at banks and homes had less mean monthly income than those with absence of such saving. Instead of investing their saving in order to boost their production and increase their productivity, households preferred to keep their saving in banks and to use it at times of uncertainties. More than 34 percent of the respondents who do not have saving at banks or homes, stated that they invested their money buying productive assets for their agricultural activities. Meanwhile less than $23 \%$ of those who had saving used this money to invest in agricultural activities. Data showed that farmers with less saving had more equipment, livestock and land size. Also data showed that farmers who had less savings were involved in various in-farm and off-farm activities in order to generate more income. While those who had more savings just depended on their farm activities as they feel safer and believed that if any uncertainties occurs they can manage by using their savings. Therefore, in order to eradicate poverty, households should implement productive strategies and get involved in other programs and activities that can generate more income. Investing in productive assets found to be more effective rather than savings in the banks or at home.

\section{Conclusion}

In summary, this study addressed and examined the role of assets and entitlements in enhancing households' wellbeing in rural communities in Kelantan and Terengganu in Malaysia.

Based on the results of this study, human, natural and physical capital are the fundamental keys in combating poverty. While the above three capitals significantly increase households' monthly income; social capital has no effect on farmers' monthly income; and financial capital found to have negative impact on farmers' monthly income. The results indicate that those who had not suffered from sickness found to have different mean monthly income from those who had suffered from the sickness. Meanwhile, educational level seems not to have any effect on households' wellbeing. Therefore, it is the level of skills and "health condition" for both productive and non-productive households that play the most important role in increasing their monthly incomes and not their formal education. People who have access to social capital have no difference in the mean monthly income with those who do not have access to social capital. This was explained by two facts: first, the lack of access to or even the absence of citizens' associations. And second, majority of households' respondents in these communities are poor with some living in hardcore poverty and their relatives and friends are unable to assist them because they are also poor. While the results show that those who have more livestock (cows, sheep, hens and ducks), mechanical tractors, land and fertilizers produce more and the surplus of their production (after consuming or storing their families' needs) sold in local market. The results also indicated that those who have access to irrigation feel safer and therefore they just get involved in limited activities that prevent them from any unexpected events. Consequently, they became more vulnerable to income diversification. Also the results indicated that those who have savings at banks and homes have less mean monthly income than those who do not have savings. Instead of using this savings and investing it in order to boost their production and increase their productivity, households preferred to keep their savings at banks and to use them during periods of uncertainties. It can be concluded that access to resources may not enhance households' welfare unless these resources are used adequately and effectively. Consequently, in order to get out of poverty, households should implement productive 
strategies that generate more income. Investing in productive assets was found to be more effective rather than save their money either at banks or at home.

\section{Acknowledgements}

The authors acknowledge that the present research work was aided with funds from USM Postgraduate Research Grant Scheme (USM-RU-PRGS) Account Number 1001/PSOCIAL/843069. The usual disclaimer applies. Any remaining errors or omissions rest solely with the researchers of this work. The main author acknowledges the Universiti Sains Malaysia for its support of USM fellowship Scheme.

\section{References}

Acosta-Michlik, L., \& Espaldon, V. (2008). Assessing vulnerability of selected farming communities in the Philippines based on a behavioural model of agent's adaptation to global environmental change. Global Environmental Change, 18, 554-563. http://dx.doi.org/10.1016/j.gloenvcha.2008.08.006

Adger, W. (2006). Vulnerability. Global Environmental Change, 16, 268-281. http://dx.doi.org/10.1016/j.gloenvcha.2006.02.006

Ashfaq, M., Saboor, A., \& Hussain, M. (2001). Using irrigation management for poverty alleviation: a descriptive analysis. Pakistan Journal of Applied Sciences, 1(1), 64-66.

Babatunde, R. O. (2008). Income portfolios in rural Nigeria: Composition and determinants. Trends in Agriculture Economics, 1(1), 35-41. http://dx.doi.org/10.3923/tae.2008.35.41

Bokosi, F. K. (2007). Households' poverty dynamics in Malawi: A Bivariate Probit analysis. Journal of Applied Sciences, 7(2), 258-262. http://dx.doi.org/10.3923/jas.2007.258.262

Carter, M. R., Little, P. D., Mogues, T., \& Negatu, W. (2007). Poverty traps and natural disasters in Ethiopia and Honduras. World Development, 35(5), 835-856. http://dx.doi.org/10.1016/j.worlddev.2006.09.010

Dercon, S. (2004). Growth and shocks: evidence from rural Ethiopia. Journal of Development Economics, 74(2), 309-329. http://dx.doi.org/10.1016/j.jdeveco.2004.01.001

Devereux, S. (2001). Livelihood Insecurity and Social Protection: A Re-Emerging Issue in Rural Development. Development Policy Review, 19(4), 507-519. http://dx.doi.org/10.1111/1467-7679.00148

Economic Planning Unit and Department of Statistics Malaysia. Household Income Survey, 2004-2009. Retrieved from http://www.epu.gov.my/html/themes/epu/html/RMKE10/rmke10_english.html

Economic Planning Unit EPU. (2010). Incidence of Poverty by Ethnicity, Strata and State, Malaysia, 1970-2009. Retrieved 12 April, 2010, from http://www.epu.gov.my/household-income-poverty

Fafchamps, M., \& Quisumbing, A. R. (1998). Human capital, productivity, and labor allocation in rural Pakistan. Food Consumption and Nutrition Division. Paper No 48.

Geest, K. vander, \& T. Dietz. (2004). A literature survey about risk and vulnerability in drylands, with a focus on the Sahel. In A. J. Dietz, R. Ruben, \& A. Verhagen (Eds.), The Impact of Climate Change on Drylands, with a focus on West Africa (pp. 117-146). http://dx.doi.org/10.1007/1-4020-2158-5_11

Grootaert, C. (1999). Social capitals, household welfare, and poverty in Indonesia (Local Level Institutions Study Working Paper No. 6). Washington, DC: World Bank.

Grootaert, C., \& Narayan, D. (1999). Local institutions, poverty and household welfare in Bolivia (Local Level Institutions Study Working Paper No. 9). Washington, DC: World Bank.

Grootaert, C., Oh, G., \& Swamy, A. (2002). Social capital, household welfare and poverty in Burkina Faso. Journal of African Economics, 11, 4-38. http://dx.doi.org/10.1093/jae/11.1.4

Haidar, M. (2009, December). Sustainable Livelihood Approaches the Framework, Lessons Learnt From Practice and Policy Recommendations. Economic and Social Commission for Western Asia (ESCWA) Beirut.

Hanjra, M. A., Ferede, T., \& Gutta, D. G. (2009). Reducing poverty in sub-Saharan Africa through investments in water and other priorities. Agricultural Water Management, 96, 1062-1070. http://dx.doi.org/10.1016/j.agwat.2009.03.001

Hussain, I., \& Hanjra, M. A. (2003). Does irrigation water matter for rural poverty alleviation? Evidence from South and South-east Asia. Water Policy, 5, 429-442.

Hussain, I., \& Hanjra, M. A. (2004). Irrigation and poverty alleviation: review of the empirical evidence. 
Irrigation and Drainage, 53, 1-15. http://dx.doi.org/10.1002/ird.114

Jehangir, W. A., Ashfaq, M., Ali A., \& Sarwar, N. (2002). Use of Credit for Poverty Reduction by Small Farmers, Pakistan. Journal of applied sciences, 2(7), 777-780.

Kapoor, S., \& Ojha, R. K. (2006). Vulnerability in Rural Areas: Potential Demand for Micro-Finance. International Journal of Rural Management, 2(1), 67-83. http://dx.doi.org/10.1177/097300520500200104

Khan, S., \& Nafees, M. (2002). Enhancement of agricultural production through sustainable agriculture and poverty alleviation in Kot, Manazary Baba (Malakand Agency) Pakistan. Pakistan Journal of Applied Sciences, 2(5), 584-588.

Maluccio, J., Haddad, L., \& May, J. (1999). Social capital and income generation in South Africa, 1993-1998 (Food Consumption and Nutrition Division Discussion Paper No. 71).Washington, DC: International Food Policy Research Institute.

Mathbor, G. M. (2007). Enhancement of community preparedness for natural disasters: The role of social work in building social capital for sustainable disaster relief and management. International Social Work, 50(3), 357-369. http://dx.doi.org/10.1177/0020872807076049

Moser, C. O. N. (2006, November). Asset-based Approaches to Poverty Reduction in a Globalized Context: An introduction to asset accumulation policy and summary of workshop findings. Global Economy and Development, The Brookings Institution.

Narayan, D., \& Pritchett, L. (1999). Cents and sociability: Household income and social capital in rural Tanzania. Economic Development and Cultural Change, 47(4), 871-897. http://dx.doi.org/10.1086/452436

Noriyah Ahmad. (2007). Over View of Poverty Eradication in Malaysia. Economic Planning Unit, Malaysia.

Oladoja, M. A., \& Olusanya, T. P. (2009). Impact of private feed formulation and production as a tool for poverty alleviation among poultry farmers in Ogun state Nigeria. International Journal of Poultry Sciences, 8(10), 1006-1010. http://dx.doi.org/10.3923/ijps.2009.1006.1010

Omalehin, Ra., Ogunfiditini, T. O., \& Adeniji, O. B. (2007). Factors influencing adoption of chemical pest control in cowpea production among rural farmers in Makarfi Local Government Area of Kaduna State Nigeria. International Journal of Agricultural Research, 2(11), 920-928. http://dx.doi.org/10.3923/ijar.2007.920.928

Osman-Elasha, B. et al. (2006, October). Adaptation strategies to increase human resilience against climate variability and change: Lessons from the arid regions of Sudan. AIACC Working Paper No. 42

Owuor, G., Ngigi, M., Ouma, A. S., \& Birachi, E. A. (2007). Determinants of rural poverty in africa: the case of small holder farmers in Kenya. Journal of Applied Sciences, 7(17), 2539-2543. http://dx.doi.org/10.3923/jas.2007.2539.2543

Ruben, R., \& Strien, D. (2001, September). Social capital and household income in Nicaragua: The economic role of rural organization and farmers' networks. Paper presented at the 74th European Association of Agricultural Economists (EAAE) Seminar, Wye College, UK.

Scaramozzino, P. (2006, October). Measuring Vulnerability to Food Insecurity. ESA Working Paper No. 06-12.

Schwarze, S., \& Zeller, M. (2005) Income diversification of rural households in Central Sulawesi, Indonesia. Quarterly Journal of International Agriculture, 1(44), 61-73.

Sen, A. (1981). Poverty and Famines: an Essay on Entitlement and Deprivation. Oxford: Clarendon Press.

Shah, N. H., Inamulla, Hassan, G., \& Khan, F. U. (2006). Role of intensive management of weat in poverty alleviation of NWFP Pakistan. Asian journal of plant sciences, 5(2), 190-192. http://dx.doi.org/10.3923/ajps.2006.190.192

Van Ha, N., Kant, S., \& Maclaren, V. (2004). The Contribution of Social Capital to Household Welfare in a Paper-Recycling Craft Village in Vietnam. Journal of Environment \& Development, 4(13), 371-399. http://dx.doi.org/10.1177/1070496504268345

Walusimbi, R., \& Nkonya, E. (2004). Community and household-level income \& asset status baseline survey report. Southwestern Uganda sustainable natural resources management (SUNAREM) project.

Wie, L. (2001). The effect of human resource development on household income in selected poor areas of rural China. Journal of labor and management in development, 2(2), 1-23. 